Hab. - On the under side of the leaves of Spiraea salicifolia, at Methuen, Mass., and on the under side of the leaves of Prinos verticillatus, at Andover, Mass., 1898 (in the woods at each place). The young begin to appear about July ro and the full grown scale with ovisac the following May. The scales become dry and drop off about the last of June, none can be found in July. When I sent this coccid to Prof. Cockerell last year, he, then being very busy, made a hasty examination of my mount and scales with ovisac. Some of the ovisacs did not have any scales, and I did not state this to him at that time. The mount showed the antennae to be almost indentical with those of Lichtensia viburni Sign., and he supposed it to be a variety of that species. Being later doubtful of this, he requested me to study the insect with better material, and the result has been to prove that it cannot belong to Lichtensia, as it does not have the scale covered with its ovisac.

\section{Antennal Segments.}

$\begin{array}{lcccccccc} & \text { I } & 2 & 3 & 4 & 5 & 6 & 7 & 8 \\ \text { Length } & 56 & 44 & 88 & 60 & 44 & 28 & 24 & 52 \\ \text { Width } & 80 & 56 & 36 & 28 & 24 & 20 & 20 & 16 \\ \text { Formula } & 3418(25) & 76 . & & & & & \end{array}$

Measurements of Leg.

\begin{tabular}{|c|c|c|c|c|c|}
\hline & Coxa & $\begin{array}{l}\text { Femur } \\
\text { with } \\
\text { Tro- Tibia } \\
\text { chanter }\end{array}$ & Tarsus & Claws & $\begin{array}{l}\text { Tarsal Claw } \\
\text { Digi- Digi- } \\
\text { tules tules }\end{array}$ \\
\hline er & I I 2 & $264 \times 76$ & 84 & 24 & 36 \\
\hline idth & $\mathrm{I}_{4} \mathrm{O}$ & $92 \quad 44$ & 28 & 28 & \\
\hline
\end{tabular}

Lawrence, Mass.

\section{JANET'S RECENT OBSERVATIONS ON ANTS, ETC.}

Several recent papers* by Charles Janet,

\footnotetext{
* Note 17. Système glandulaire tégumentaire de la Myrmica rubra. Observations diverses sur les Fourmis. 30 pp. 9 figs. Paris, 1898 .
}

the well known authority upon ants, wasps, and bees, deserve mention. All are written in the concise and clear style characteristic of the author.

In Note $\mathbf{1} 7$, nine classes of glandular organs are defined, of which the integumentary system alone comprises eight pairs: (I) Unicellular glands opening separately at the bases of the antennae. (2) Well developed unicellular glands with a common reservoir at the base of either mandible. (3) Maxillary glands. (4) Labial glands, derived from the larval silk glands. (5) Glands of the median segment, possibly odoriferous to enable members of the same colony to recognize one another. (6) Poison glands of the female, also accessory glands, alkaline in reaction, serving - the author suggests - neither to lubricate the sting nor to complete the composition of the poison, but to neutralize superfluous formic acid remaining upon the insect itself. (7) Glands of the sheath, also represented by certain glands in the male. (8) Glands of the ninth segment.

All the integumentary glands except the poison glands secrete alkaline fluids which are believed to protect ants from the deleterious effects of their own formic acid. Thus, Janet finds that formicaries give an alkaline reaction which varies in rapidity and strength according to the species of ant and

Note 18. Aiguillon de la Myrmica rubra. Appareil de fermeture de la glande à venin. 27 pp., 3 pls., 5 text flgs. Paris, 1898 .

Note ig. Anatomie du corselet de la Myrmica rubra reine. Mém. soc. zool. France, I898. pp. 393-450, pl. 6, 25 text figs.

Extr. comptes rend. séances acad. sc. : -

No. 12. Sur une cavité du tégument servant, chez les Myrmicinae, à étaler, au contact de l'air, un produit de sécrétion. T. 126 (1898), 4 pp.

No. 13. Réaction alcaline des chambres et galeries des nids de Fourmis. Durée de la vie des Fourmis décapitées. T. ${ }_{27}$ (1898), 4 pp. :

14. Sur un organe non décrit servant à la fermeture du réservoir du venin, et sur le Mode de fonctionnement de l'aiguillon chez les Fourmis. T. 127 (1898), 4 pp.

No. 15. Sur le mecanisme du vol chez les Insectes. T. 128 (1899), 4 pp. 
in correlation with the development of the acid and alkaline glands of that species.

This paper also records a number of miscellaneous observations upon the cleanliness of ants' nests, the vitality of queens, etc. and portions of the paper are republished in Nos. 12 and 13.

Note 18 is a valuable contribution to the literature upon the hymenopterous sting. The organ in Myrmica is thoroughly described and figured, the results of other workers being supplemented by numerous original observations. The apparatus controlling the flow from the poison gland is described for the first time in Note 18 , from which No. I4 is an extract.

Note 19 is an important paper of nearly sixty pages upon the anatomy of the thor-. acic region which, as including the median segment, is termed corselet. Eight clear figures express the forms and relations of the thoracic sclerites. Only one who has undertaken a similar subject can appreciate the success with which the author has explained the positions and functions of the thoracic muscles, especially those concerned in flight. Although the paper deals chiefly with a single species in a purely descriptive way, the character and number of the illustrations, abundantly facilitate the comparison of Myrmica with other groups by the morphologist. Paper No. 15 is a repetition of a part of Note 19.

The amount of study represented by the interesting papers of Janet is frequently disguised by the author's conciseness of expression.

\section{THE PANURGINE BEES.}

With reference to Mr. Ashmead's article on pp. $372-376$, the following remarks may be appropriate :-

(I.) Perdita (Corkerellia) hyalina $\delta$ has the hind claws simple, and the front and middle claws deeply cleft. So also pasonis and other allied forms. I have examined Cresson's type of hyalina in Philadelphia. The $\delta$ of beata, the type of Philoxanthus. is unknown.

(2.) Parandrena Rob., has nothing to do with Panurginus!

(3.) Biareolina is ordinary Andrena with two submarginal cells ; Callandrena is apparently derived from a very distinct section of Andrena belonging to North America ( $A$. pulchella $\&$ c.). It is quite impossible to imagine that these genera have any bloodrelationship, except through Andrena; consequently, they cannot be united.

(4.) Hemihalictus is I believe, an American derivative of Halictus, its resemblance to Dufourea being due to convergence. There is a marked difference in the venation, the first recurrent nervure in Dufourea joining the second submarginal cell at its extreme base, while in Hemikalictus it joins it not far from the middle. Mr. Ashmead tells nre, however, that he has seen an undescribed species presenting intermediate characters.

(5.) Hesperapis (not Hesperaspis) is very distinct from lRhophitoides by the short dagger-like tongue, as originally described by me.

(6.) Pseudopanurgus is a compact and easily recognized group, belonging to the arid region; it is a matter of taste whether one calls it a genus or a subgenus of Panurginus.

(7) Nomadopis I can now accept, because the species on which it was founded is not the Perdita zonalis Cr., but a species quite distinct from any Perdita. I had the pleasure of seeing it recently in the Nat. Museum.

It is hardly necessary for me to say, that I value extremely Mr. Ashmead's table of bees; and disagreement as to details must not be taken for disparagement of the whole.

\section{T. D. A. Cockerell.}

N. M. Agr. Exp. Sta. 

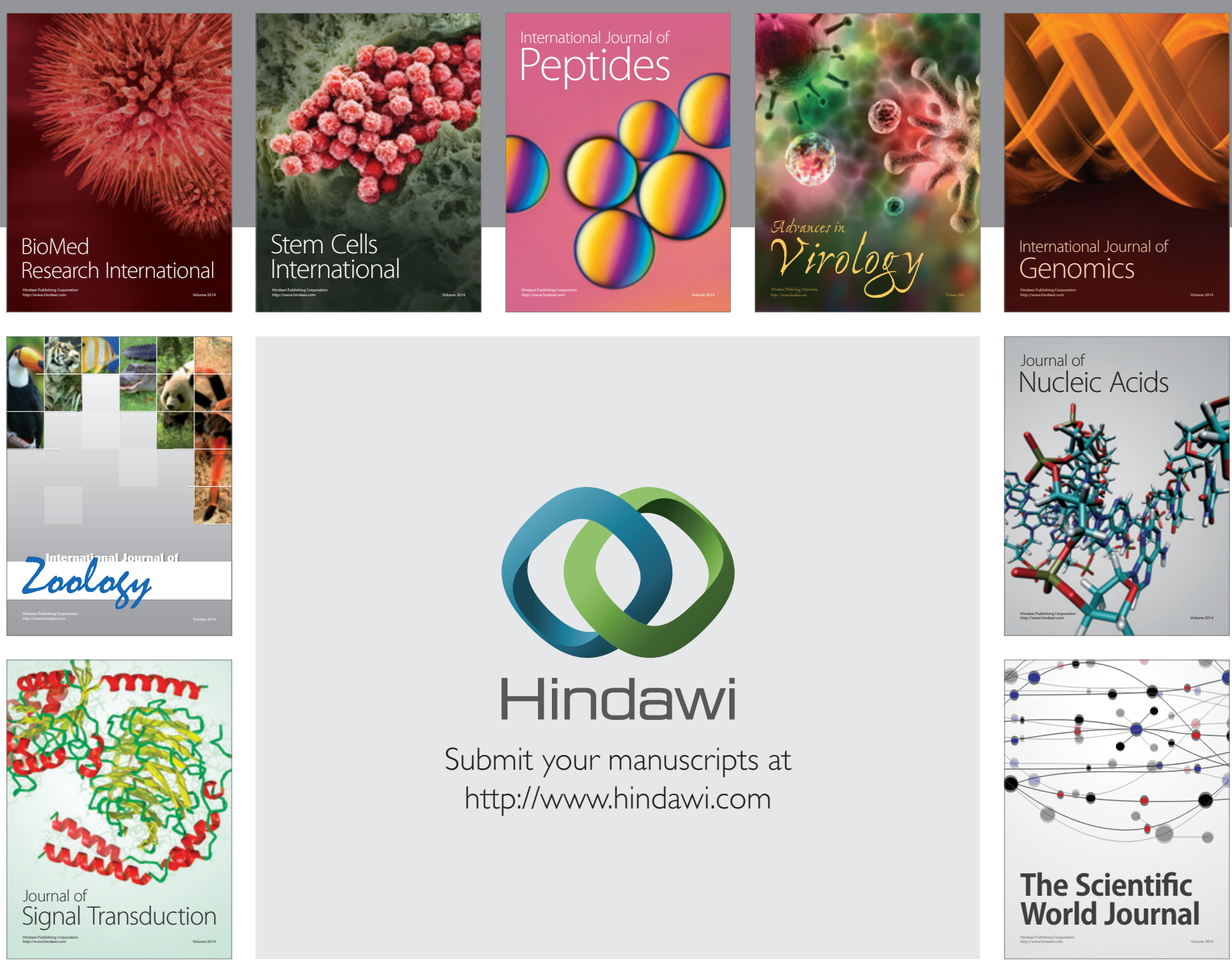

Submit your manuscripts at

http://www.hindawi.com
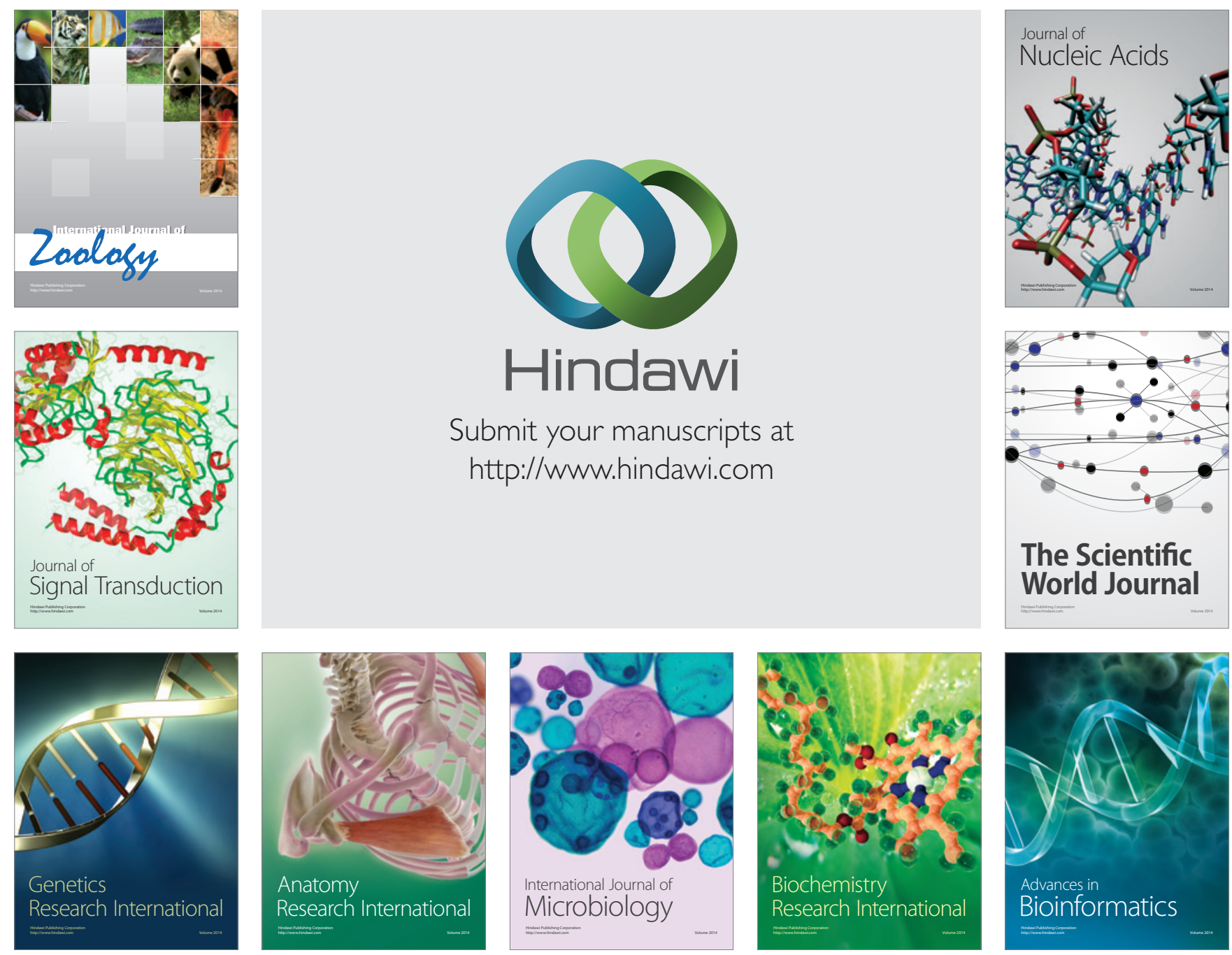

The Scientific World Journal
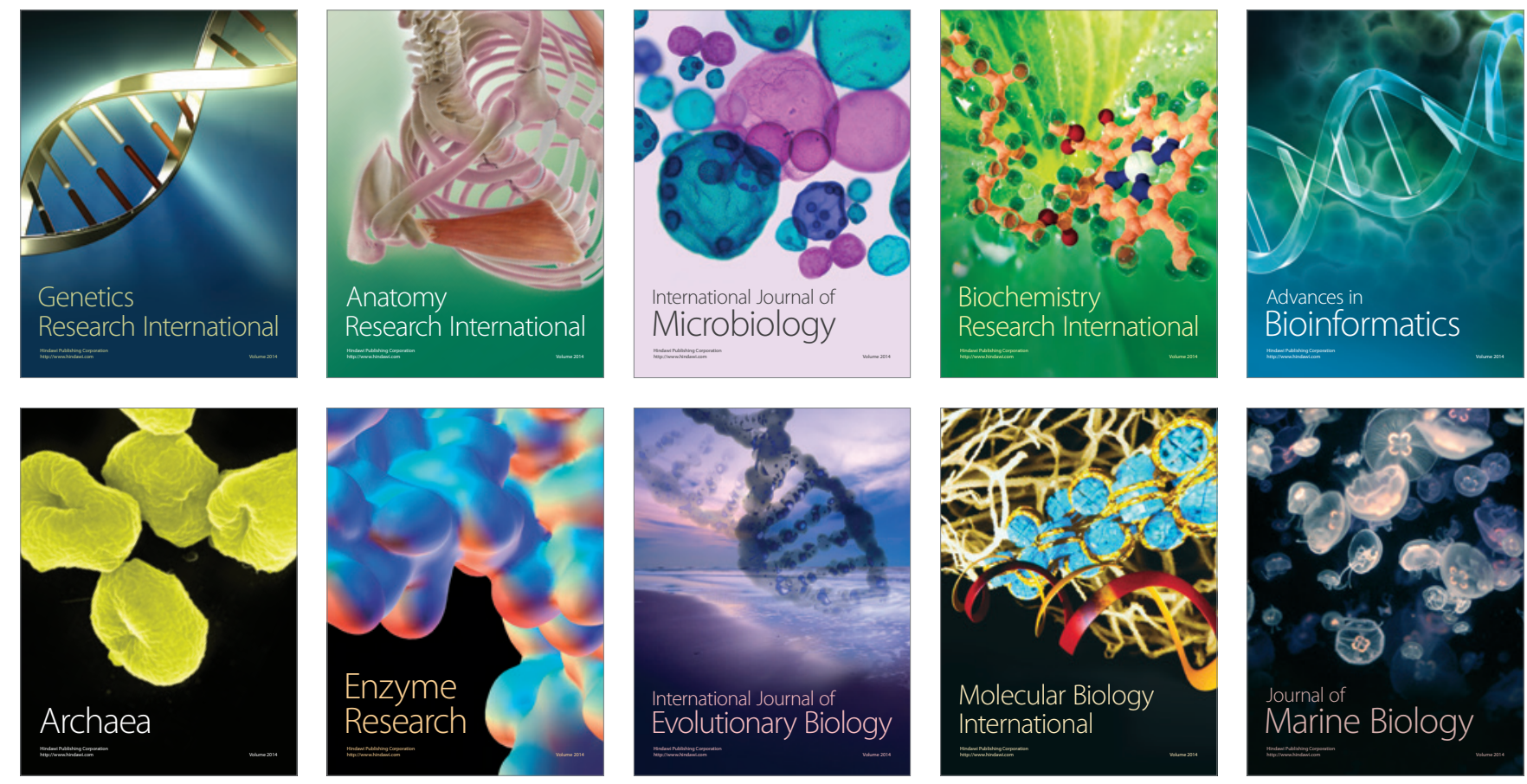